E3S Web of Conferences 1, 15008 (2013)

DOI: $10.1051 / \mathrm{e} 3$ sconf/20130115008

(c) Owned by the authors, published by EDP Sciences, 2013

\title{
Copper and Zinc Uptake by Pakchoi and Rice as Affected by Applying Manure Compost with Different Levels of $\mathrm{Cu}$ and $\mathrm{Zn}$ Concentrations
}

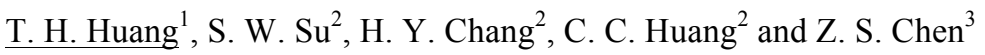 \\ ${ }^{1}$ Department of Agricultural Chemistry, National Taiwan University, Taipei 106, TAIWAN, r00623002@ntu.edu.tw \\ ${ }^{2}$ Department of Agricultural Chemistry, National Taiwan University, Taipei 106, TAIWAN, \\ ${ }^{3}$ Department of Agricultural Chemistry, National Taiwan University, Taipei 106, TAIWAN, soilchen@ntu.edu.tw
} Abstract. $\mathrm{Cu}$ and $\mathrm{Zn}$ are frequently added to livestock diets as additives to increase feed efficiency and production. This practice resulted in the higher contents of $\mathrm{Cu}$ and $\mathrm{Zn}$ in excrement of livestock. The aim of this study is to evaluate the effect of $\mathrm{Cu}$ and $\mathrm{Zn}$ concentration of manure compost and its application rates on the production and quality of pakchoi and rice. The pot experiments were conducted and the six manure compost were applied at 3 rates $(20,40$, and 80 ton/ha), including the control and chemical fertilizer treatments. Results showed that the yield of the crops was enhanced by the compost application, and the $\mathrm{Cu}$ and $\mathrm{Zn}$ concentration in the edible part of crops were in normal range (pakchoi: $\mathrm{Cu} 1.8-10.4 \mathrm{mg} / \mathrm{kg}, \mathrm{Zn}$ $39-160 \mathrm{mg} / \mathrm{kg}$; rice grain: $\mathrm{Cu} 0.6-4.0 \mathrm{mg} / \mathrm{kg}, \mathrm{Zn} 58-79 \mathrm{mg} / \mathrm{kg}$ ). The potential risk of long-term manure compost application on soil quality was also evaluated. The total $\mathrm{Zn}$ concentration in soils may reach the regulation standard after 22 years of manure compost application at the rate of 40 ton/ha/year.

Key words: $\mathrm{Cu}, \mathrm{Zn}$, manure, compost, pakchoi, paddy rice, bioavailability.

\section{Introduction}

Soil organic matter plays a critical role in the sustainability of agroecosystem and it is also an important indicator of the soil quality and productivity. Intensive agriculture system and subtropical climate in Taiwan accelerate the decomposition of soil organic matter. Chen and Hseu (1997) reported that the organic matter contents of commonly cultivated soils in Taiwan are generally low, ranged from $1.3 \%$ to $2.4 \%$. Therefore, the application of organic fertilizer is important for the nutrient supply in soils and maintainance of soil quality. The use of organic fertilizer has received great attention from researchers who investigated the sustainability and productivity of rural soils in last two decades (Shu and Chung, 2006).

Lots of agriculutral residues and livestock wastes were recycled for composting in Taiwan. Hseu (2004) found that the concentration of $\mathrm{Cu}$ and $\mathrm{Zn}$ in manure compost were significantly higher than the regulation of metals in the composts in Taiwan. Excessive application of manure compost may cause negative effects on the environment, such as the accumulation of salts or heavy metals in soils (Diez et al., 2001).

The objectives of this study were (1) to find out the appropriate application rate of manure compost and (2) to evaluate the potential risk of long-term manure compost application on the soil quality and the crop quality .

\section{Materials and Methods}

Pot Experiment

The pot experiment was conducted in the phytotron of National Taiwan University. The humidity was 70 to $95 \%$, and the temperature was maintained at 25/20 during the day and night.

Air-dried silt clay soil $(3.5 \mathrm{~kg})$ was thoroughly mixed with the manure compost in the $1 / 5000$ a Wager pot. The application rates were 20,40 , and 80 ton/ha, There were 20 treatments including 18 treatments with different compost rates and a non-fertilized control treatment $(\mathrm{CK})$ and a conventional chemical fertilizer treatment $(\mathrm{CF})$. Seedlings of pakchoi (Brassica rape L., leaf vegetable) were grown in pots until harvest and followed by the growth of rice (Oryza sativa L.). The soil moisture content was maintained at field capacity during the growth of pakchoi. For rice, pots were flooded with $3-5 \mathrm{~cm}$ of water above the soil surface during the whole rice growth period. All the treatments were 4 replicates by a completely randomized design.

The pakchoi and rice were harvested after the growth of 30 days and 120 days, respectively. The soils were sampled at the same time. The shoot of pakchoi and 
rice grain were washed with deionized water, oven-dried at 70 for 2 days. All the crop samples were ground to pass through a 40 mesh sieve $(<0.5 \mathrm{~mm})$.

Soil bioavailability of $\mathrm{Cu}$ and $\mathrm{Zn}$ was determined by extraction by using the reagent $0.01 \mathrm{M} \mathrm{CaCl}_{2}$ (soil:water $=1: 10)$. The pakchoi or rice grain powder $(0.5 \mathrm{~g}$ dried weight) were digested by concentrated $\mathrm{H}_{2} \mathrm{SO}_{4}$ and $30 \%$ $\mathrm{H}_{2} \mathrm{O}_{2}$ and heated at $250^{\circ} \mathrm{C}$ for $30 \mathrm{~min}$. The concentrations of $\mathrm{Cu}$ and $\mathrm{Zn}$ of all solutions were determined by the ICP-AES.

\section{Statistical Analysis}

Data were analyzed by analysis of variance in a factorial design. The mean values of treatments were compared by Duncan's multiple range tests. Statistical significance level was defined at $p=0.05$.

\section{Results and Discussion}

\section{Characteristics of Manure Compost}

Table 1 showed the chemical properties of the manure compost and the studied soil for the pot experiments. The main differences of studied compost are the concentrations of $\mathrm{Cu}$ and $\mathrm{Zn}$. The concentrations of $\mathrm{Cd}$, $\mathrm{Cr}, \mathrm{Ni}$, and $\mathrm{Pb}$ of all studied composts were meet the regulation of composts in Taiwan and acceptable for the application into the soils (data not shown).

\section{$\mathrm{Cu}$ and $\mathrm{Zn}$ contents of the pakchoi and rice grain}

The $\mathrm{Cu}$ and $\mathrm{Zn}$ concentrations of pokchoi $(\mathrm{Cu}$ : 1.8-10.4 $\mathrm{mg} / \mathrm{kg}$; Zn: $39-160 \mathrm{mg} / \mathrm{kg}$ ) was higher than those of rice grain $(\mathrm{Cu}: 0.6-4.0 \mathrm{mg} / \mathrm{kg} ; \mathrm{Zn}: 58-79 \mathrm{mg} / \mathrm{kg})$. Generally speaking, the $\mathrm{Cu}$ concentration of plants is below 25 $\mathrm{mg} / \mathrm{kg}$ and the $\mathrm{Zn}$ concentration is on $20-400 \mathrm{mg} / \mathrm{kg}$ (Epstein, 1997). The regulations of $\mathrm{Cu}$ and $\mathrm{Zn}$ in crops around the world are 20 and $100 \mathrm{mg} / \mathrm{kg}$ (Lin et al., 2002). $\mathrm{Cu}$ and $\mathrm{Zn}$ are micronutrient for crops and human. The $\mathrm{Zn}$ concentration of pakchoi tissue was $123 \mathrm{mg} / \mathrm{kg}$ under the treatment of $\mathrm{CF}$, which was similar to those of all other treatments of manure compost. Furthermore, no adverse effects were found on the growth and production of pakchoi. The $\mathrm{Cu}$ and $\mathrm{Zn}$ concentrations of rice grain were not enhanced by the application of manure compost, even the total $\mathrm{Cu}$ and $\mathrm{Zn}$ concentrations in soils was increased (Figure 1).

\section{Soil bioavailability of $\mathrm{Cu}$ and $\mathrm{Zn}$ after compost application}

After the compost application, the total $\mathrm{Cu}$ and $\mathrm{Zn}$ concentrations of soil were significantly increased (data not shown). The concentration of extractable $\mathrm{Zn}$ is positively correlated with the total $\mathrm{Zn}$ in soil (42-131 $\mathrm{mg} / \mathrm{kg}$ ) (Figure. 2a). A good correlation between the bioavailable $\mathrm{Zn}$ in soil and the $\mathrm{Zn}$ concentration in pakchoi is observed (Figure. 2b). This may be explained by the high mobility of $\mathrm{Zn}$ in soils. The same findings were reported in the previous study (Zhou et al., 2005). The $\mathrm{Zn}$ concentration in rice grain showed no correlation with the bioavailable $\mathrm{Zn}$ in soil. Rice was cultivated in the flooded system and the reduction reaction might increase soil $\mathrm{pH}$. This may decrease the mobility of $\mathrm{Zn}$ in soils. Although the total $\mathrm{Cu}$ concentration in soil is elevated $(15-52 \mathrm{mg} / \mathrm{kg})$, the level of $\mathrm{Cu}$ in rice grain is at normal range (Figure 1b). The increase of soil $\mathrm{pH}$ in the flooded situation and the strong binding of $\mathrm{Cu}$ and the organic matter might contribute to the immobilization of $\mathrm{Cu}$ in soils.

The effect of long-term application on the soil quality and the food safety

The data supported the fact that the crop yield was enhanced by compost application, while the $\mathrm{Cu}$ and $\mathrm{Zn}$ concentrations in soils were also increased in those treatments. Therefore, it is necessary to assess the risk of long-term compost application on the crop safety and soil quality. Two approaches were taken in this study: (1) to evaluate the potential accumulation of $\mathrm{Cu}$ and $\mathrm{Zn}$ in pakchoi to evaluate the maximum compost application capacity of the soil and (2) to estimate the soil accumulative application capacity of the compost based on the $\mathrm{Cu}$ and $\mathrm{Zn}$ regulation standard of Taiwan rural soil.

(1) The $\mathrm{Zn}$ concentration in plant tissue is varieties dependent, $25-400 \mathrm{mg} / \mathrm{kg}$ is recognized as normal ranges (Pendias and Pendias, 2001; Epstein, 1997). Cu and Zn are microelements but essential elements for crops. We assumed the regulation value of pakchoi is $200 \mathrm{mg} / \mathrm{kg}$ (as $y$ axis), then the regression formula can be listed as following:

$$
y=59.78 x+29.39(\text { Figure } 2 b)
$$

We got $\mathrm{x}=2.85 \mathrm{mg} / \mathrm{kg}$ as soil extractable $\mathrm{Zn}$ concentration. Furthermore, it may be reasonable to access the total $\mathrm{Zn}$ concentration (as $x$ axis) in soil by applying $2.85 \mathrm{mg} / \mathrm{kg}$ (as $y$ axis) into the formula subjecting to:

$$
y=0.0148 x-0.4497(\text { Figure 2a) }
$$

We got $\mathrm{x}=223 \mathrm{mg} / \mathrm{kg}$. The result implied that when the total $\mathrm{Zn}$ concentration of soil approached to 223 $\mathrm{mg} / \mathrm{kg}$ by compost application, the $\mathrm{CaCl}_{2}$ extractable $\mathrm{Zn}$ concentration in soil might around $2.85 \mathrm{mg} / \mathrm{kg}$. This may result in $\mathrm{Zn}$ concentration in pakchoi reached to around $200 \mathrm{mg} / \mathrm{kg}$, which is still recognized as safety.

(2) The soil function to attenuate the heavy metal toxicity should be taken into account. Therefore, the maximum loading capacity of compost can be estimated. According to the Soil and Groundwater Pollution Remediation Act of Taiwan EPA, the regulation of $\mathrm{Cu}$ and $\mathrm{Zn}$ of rural soil is 200 and $600 \mathrm{mg} / \mathrm{kg}$, respectively. 

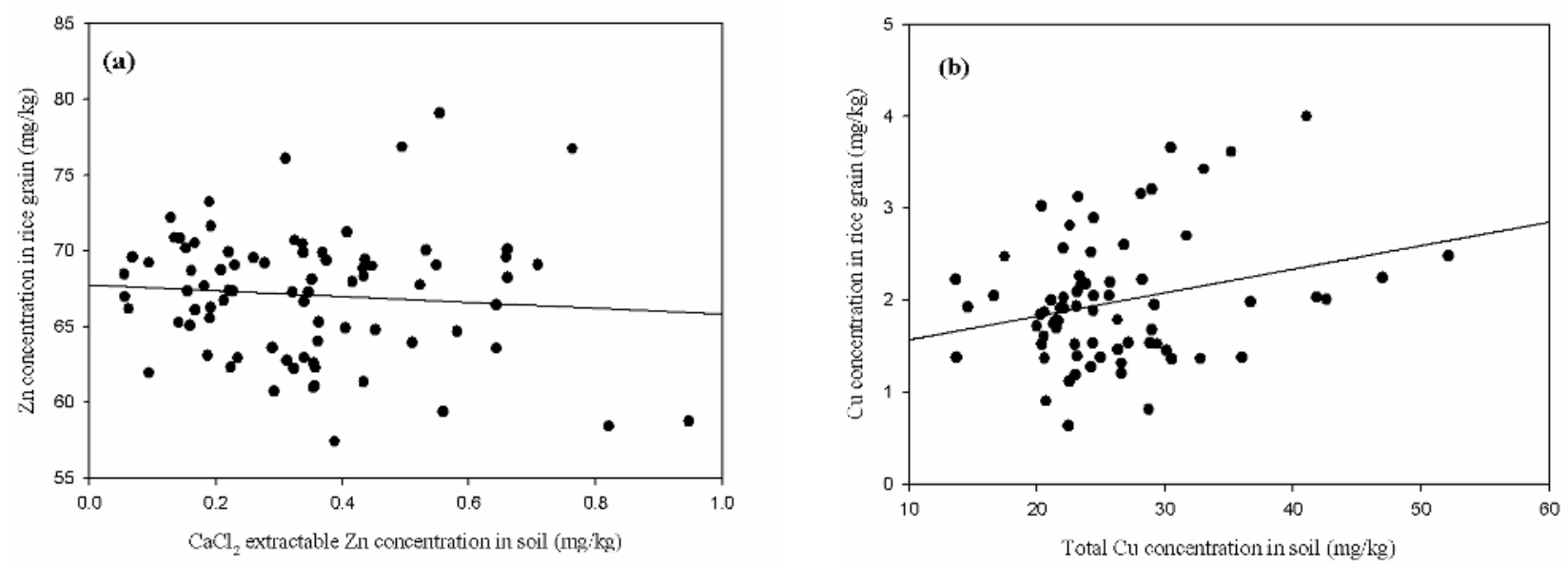

Fig. 1. The relationship between (a) $\mathrm{CaCl}_{2}$ extractable $\mathrm{Zn}$ concentration in soil and $\mathrm{Zn}$ concentration in grain; (b) Total $\mathrm{Cu}$ concentration in soil and $\mathrm{Cu}$ concentration in grain. (All treatments in a plot ).
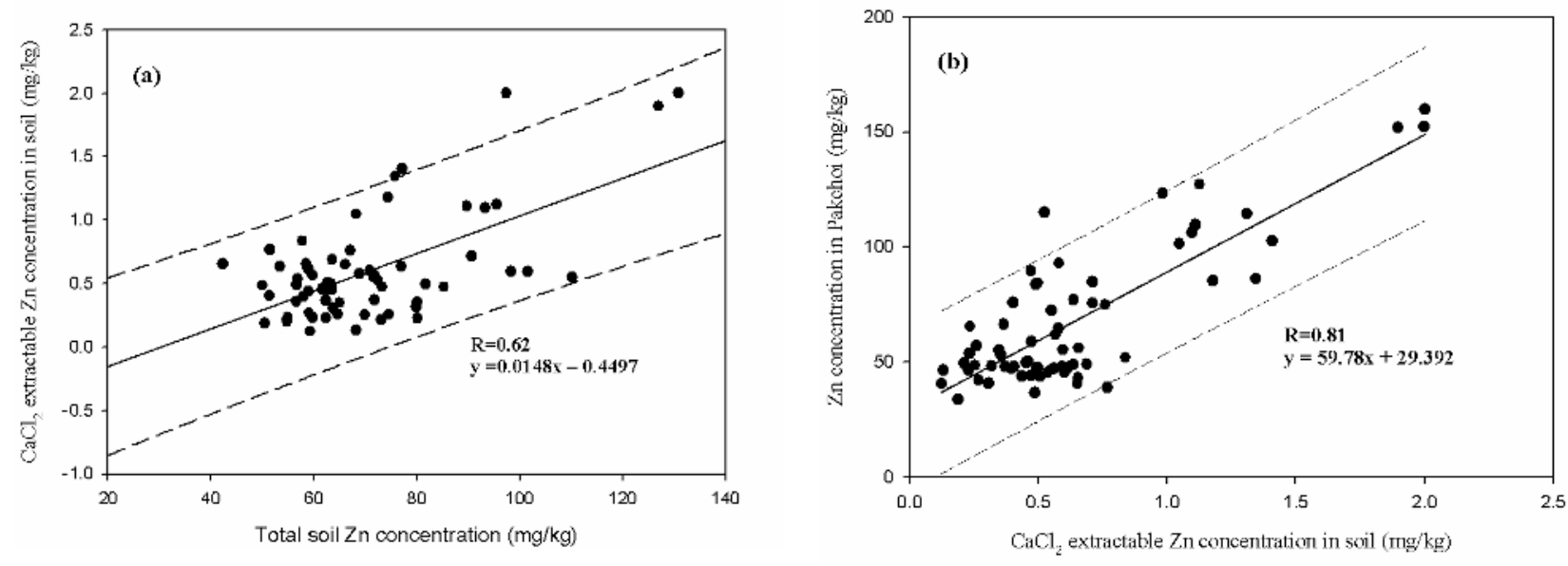

Fig. 2. The relationship between (a) Total $\mathrm{Zn}$ in soil and $\mathrm{CaCl}_{2}$ extractable $\mathrm{Zn}$ concentration in soil; (b) $\mathrm{CaCl}_{2}$ extractable $\mathrm{Zn}$ in soil and $\mathrm{Zn}$ concentration in pakchoi. (All compost treatment in a plot, the dash lines represent the prediction of interval. ).

Table 1. The physical and chemical properties of the soil and the compost.

\begin{tabular}{lcccccc}
\hline Composts/soil & $\mathrm{pH}$ & $\mathrm{EC}$ & $\mathrm{OM} \dagger / \mathrm{OC} \dagger$ & $\mathrm{Cu}$ & $\mathrm{Zn}$ & Texture \\
\hline & \multicolumn{7}{c}{$\mathrm{dS} \mathrm{m}^{-1}$} & $\%$ & $-\cdots \mathrm{m} \mathrm{kg}^{-1}---$ & \\
\hline Compost A & 6.9 & 5.5 & $93.1 \dagger$ & 34 & 104 & - \\
Compost B & 6.3 & 10.6 & $63.9 \dagger$ & 111 & 398 & - \\
Compost C & 7.4 & 4.9 & $49.6 \dagger$ & 136 & 312 & - \\
Compost D & 6.4 & 3.4 & $71.1 \dagger$ & 156 & 520 & - \\
Compost E & 6.5 & 8.8 & $54.2 \dagger$ & 560 & 766 & - \\
Compost F & 4.8 & 12.5 & $85.5 \dagger$ & 321 & 1213 & - \\
$\quad$ Soil & 5.3 & 0.58 & $2.1 \dagger$ & 15 & 49 & Silt clay \\
\hline
\end{tabular}

$\dagger$ : OM: organic matter; $\$$ : OC: organic carbon. 
In this case, the maximum loading capacity of $\mathrm{Cu}$ is $185 \mathrm{mg} / \mathrm{kg}$ (200 subtracts 15$)$ and $\mathrm{Zn}$ is $551 \mathrm{mg} / \mathrm{kg}(600$ subtracts 49). Considering 2000 ton/ha soil in the agricultural soils (top soil $15 \mathrm{~cm}$ depth), the Maximum loading capacity of metals in soil for $\mathrm{Cu}$ is $370 \mathrm{~kg} / \mathrm{ha}$ and $\mathrm{Zn}$ is $1102 \mathrm{~kg} / \mathrm{ha}$. Maximum application rate of compost can be calculated as followings:

Maximum application rate $($ ton/ha $)=[$ Maximum loading capacity of metals in soil ( $\mathrm{kg} / \mathrm{ha}) /$ heavy metal concentration in the compost $(\mathrm{mg} / \mathrm{kg})] \times 1000$

For example, the compost F with $\mathrm{Zn} 1213 \mathrm{mg} / \mathrm{kg}$, and the maximum application rate is thus 908 ton/ha. This implied that at the application rate of 40 ton/ha/year, it will take 22 years of application to increase the total $\mathrm{Zn}$ concentration in soils to reach the regulation standard.

\section{Conclusion}

Manure compost with the large range of $\mathrm{Cu}$ (34-560 $\mathrm{mg} / \mathrm{kg}$ ) and $\mathrm{Zn}(104-1213 \mathrm{mg} / \mathrm{kg})$ concentration were applied at 20,40, and 80 ton/ha/year. Both the yield of the pokchoi (leaves vegetable) and rice grain were enhanced by the application of manure compost. The yield of rice grain was further increased at higher application rate. The $\mathrm{Cu}$ and $\mathrm{Zn}$ concentration of crops were slightly increased by the application of manure compost, but they were still acceptable, pakchoi $(\mathrm{Cu}$ : 1.8-10.4 mg/kg; $\mathrm{Zn}: 39-160 \mathrm{mg} / \mathrm{kg})$, rice grain $(\mathrm{Cu}$ : $0.6-4.0 \mathrm{mg} / \mathrm{kg}$; Zn: $58-79 \mathrm{mg} / \mathrm{kg}$ ). The mobility of $\mathrm{Cu}$ and $\mathrm{Zn}$ of the paddy soil was decreased, while the soil bioavailability of $\mathrm{Zn}$ was increased in the compost treatments in the rural soil. Our evaluation indicated that the total $\mathrm{Zn}$ concentration of soils may reach the regulation standard after 22 years of manure compost application by the application rate of 40 ton/ha/year.

\section{References}

Chen ZS, Hseu ZY. Total organic pool in soils of Taiwan. In: Proceedings of the National Science Council, Taiwan, 1997, Part B: life sciences, Vol. 21, no. 3, pp. 120-127.

Diez JA, de la Torre AI, Cartagena MC, Carballo M, Vallejo A, Munoz MJ. Evaluation of the application of pig slurry to an experimental crop using agronomic and ecotoxicological approaches. J Environ Qual 2001; 30:2165-2172.

Epstein E. The science of composting. Technomic, 1997, Publishing Co. Inc., Lancaster, Pennsylvania 17604, USA.

Hseu ZY. Evaluating heavy metal contents in nine compost using four digestion methods. Bioresources Technol 2004; 95:53-59.

Kabata-Pendias A, Pendias H. Trace Elements in Soils and Plants. 2001. p.106-118. 3rd ed. CRC press, Florida, USA.

Lin HT, Weng ZS, Lee GC. The concentration of heavy metal in food and the regulation act. 2002. Taiwan Agricultural Chemicals and Toxic Substances Research Institute (TACTRI), Council of Agriculture, Taiwan.

Shu YY, Chung RS. Rice growth and nutrient accumulation as affected by different compost. Commun Soil Sci Plant Anal 2006; 37:1139-1156.

Zhou DM, Hao XZ, Wang YJ, Dong YH, Cang L. Copper and $\mathrm{Zn}$ uptake by radish and pakchoi as affected by application of livestock and poultry manures. Chemosphere 2005; 59:167-175. 